Original Research Paper

\title{
Efficient Breeding in Kazakhstan Alatau Cattle Breed Population
}

\author{
${ }^{1}$ Aidar Dastanbekuly Baimukanov, ${ }^{2}$ Yusupzhan Artykovich Yuldashbayev, ${ }^{3}$ Vladimir Alexandrovich Demin, \\ ${ }^{4}$ Taram Amkhatovich Magomadov and ${ }^{5}$ Khamit Ablgazinovich Aubakirov
}

\begin{abstract}
${ }^{1}$ Faculty of Zootechnics and Biology, Russian State Agrarian University - Moscow Agricultural Academy named after K.A. Timiryazev, Moscow Agricultural Academy named after K.A. Timiryazev, Russia, Researche of ESPC Bayserke-Agro LLP, Kazakhstan

${ }^{2}$ Department of Private Animal Science, Russian State University - Moscow Agricultural Academy named after K.A. Timiryazev, Russia ${ }^{3}$ Department of the Federal State Budgetary Educational Institution of Higher Education, "Russian State Agrarian University Moscow Agricultural Academy named after K.A. Timiryazev", Russia

${ }^{4,5}$ Agrarian University, Russian State University - Moscow Agricultural Academy named after K.A. Timiryazev, Russia, Department of Biotechnology, M.H. Dulati Taraz State University, M.H. Dulati Taraz State University, Kazakhstan
\end{abstract}

\section{Article history}

Received: 31-07-2021

Revised: 30-09-2021

Accepted: 15-10-2021

Corresponding Author: Aidar Dastanbekuly

Baimukanov

Master of Zootechniks, Researche of ESPC BayserkeAgro LLP, 3 Otegen Batyr str., Talgar District, Almaty Region, 041615, Kazakhstan

Email: aidarbaimukanov98@gmail.com
Abstract: The research work aims to analyze the dynamics of the level of breeding work in the Kazakhstan Alatau cattle breed population. The research object was Alatau cattle breed from different farms of the Almaty region, differing in their breeding level and system for dairy cattle breeding. As of 01.01.2021, the population of cows of the Alatau breed in the studied farms amounted to 1578 animals, of which the largest livestock in the Khilnichenko and $\mathrm{K}$ farm is 612 or $41.1 \%$, the smallest in Mezhdurechensk-Agro LLP - 58 animals or $3.7 \%$. The average milk yield per cow of the Alatau breed for the last completed lactation for 305 days in 2020 was $5472 \pm 100.4$, in comparison with $2018(4472 \pm 151.9)$ increased by $22.4 \%$. Linear assessment of the constitutional type of the Alatau first-calf heifers in the context of farms indicates a small variation in traits between the studied farms and those close to the optimal scores of the desired type of first-calf heifers of the Alatau breed. Thus, the animals were characterized by moderate height (at an average level of 139-142 cm), average girth and depth of the body, wide chest, moderate hip inclination and hip width. In terms of limbs, the animals were also characterized by moderate stance close to the desired type. As for udder - close to the bath-shaped, with a high deep udder and correct positioning of the rear and front teats. The research results showed that the greatest interrelation was observed for the traits Central ligament $(r=+0.36)$ and "Joining of the front udder lobes" $(r=+0.31)$, which indicates a moderate and positive relation, the least interrelation was in the trait "Udder rear part height" $(\mathrm{r}=+0.11)$. Thus, for all the observed traits, a weak, moderate and positive relationship was observed, which indicates the conduct of selection and the improvement of these traits in the offspring when selecting parental pairs.

Keywords: Dairy Cattle Breeding, Brown Cattle, Alatau Breed, Milk Yield, Linear Estimation

\section{Introduction}

The main and interrelated levers of intensification of animal husbandry are breeding, full feeding, scientifically grounded production technology and optimal labour management on farms and complexes (Clasen et al., 2020).

Enhancing genetic potential of dairy productivity of cattle is achieved, firstly, by purebred breeding and secondly, by using the world's best gene pool from related breeds (Olsen et al., 2020).

In the Alatau cattle breeding, the main breeding method of dairy cattle is pure-bred breeding (Abugaliev et al., 2017).

Only breeding ensures the genetic progress of the breed, population, herd. All other components in one way or another contribute to the realization of the genetic potential (Calsamiglia et al., 2020). 
The increase in the genetic potential of the local gene pool of dairy cattle in the Republic of Kazakhstan is due to the intensity of selection, the accuracy of the genotypes assessment, genetic variation and reduction in the interval between generations. As practice shows, even the introduction of large-scale selection provides an annual progress of up to $2 \%$ (Begaliyeva et al., 2017).

It is established that the milk productivity of cows depends not only on the breeding value of their fathers, but also on mothers. Daughters from bulls - improvers and elite cows are characterized by increased phenotypic and genotypic potential of productivity, in addition, there is a development of all the signs that contribute to high fitness and adaptation to modern technologies of keeping and milking (body type, somatic cells, duration of economic use). The superiority of calves in live weight from cows with a high milk type is observed in comparison with cows with a lower milk-type index (Alenayev et al., 2017).

Of the total number of breeding livestock (824 532 animals) in 2020 in the database of the information and analytical system of the Republic of Kazakhstan, the Alatau breed amounted to 77343 animals, the Black-and-white - 62612, the Holstein black-and-white 48743, which is more (except for the black-and-white $(-9.1 \%$ in 2019 and $-4.5 \%$ in 2018$)$, respectively, by $7.3 \%$ and $21.1 \%$ than the livestock in 2019 and by $9.4 \%$ and $32.0 \%$ compared to 2018. Also, in 2020, there is an increase in the number of cows of the Alatau breed to $11.0 \%$, Black-and-white to $13.7 \%$ and Holstein blackand-white to $29.6 \%$ than the number of cows in 2018 and 2019 (Shamshidin et al., 2021).

The Alatau breed of cattle is of particular interest for the Republic of Kazakhstan. This breed is adapted for the south-eastern region of Kazakhstan. It is established that cows of the Alatau breed of the nuclear stock produce $7661 \pm 92.8 \mathrm{~kg}$ of milk, of the breeding group $-6761 \pm 71.3 \mathrm{~kg}$. On average, the cows of the Alatau breed produced milk in the amount of $7268 \pm 75.9 \mathrm{~kg}$, with a mass fraction of fat in milk $3.82 \pm 0.09 \%$. The yield of milk fat was $277.6 \pm 3.2 \mathrm{~kg}$ for cows of the Alatau breed with an average live weight of $620 \pm 17.5 \mathrm{~kg}$. In the first lactation, the milk yield averaged $6604 \pm 81.4 \mathrm{~kg}$ with an average milk fat content of $3.81 \pm 0.07 \%$. Cows reaching the third and subsequent lactation on average showed the milk yield of $8235 \pm 101.7 \mathrm{~kg}$ with a mass fraction of milk fat of $3.84 \pm 0.08 \%$. According to the live weight, all the age groups of cows exceeded the requirements of the $1 \mathrm{st}$ quality class. According to the Alatau breed of dairy cattle, there were used the bulls of the Swiss breed with the milk yield of $\mathrm{M}$ (mother) and MF (mother of the father) of $10,424-14,784 \mathrm{~kg}$ with a fat content of $3.57-3.68 \%$ (Alentayev et al., 2018).

The research results showed that in the breeding farms of Almaty, Zhambyl, Turkestan and Kyzylorda regions, the average age of fruitful insemination of heifers of the
Alatau breed is 18-20 months, heifers of the Black-andwhite breed - 16-18 months, heifers of the Holstein blackand-white breed - 1517 months when the live weight reaches $350-430 \mathrm{~kg}$ of the corresponding breed. The calf yield per 100 cows in the Alatau breed averaged $94 \%$, which is $4 \%$ more than in Black-and-white $(90 \%)$ and $10 \%$ more than in Holstein black-and-white breeds. An extended service period is observed in the Black-and-white and Holstein black-and-white breed. However, these indicators are typical for these breeds (Shamshidin et al., 2021).

The research work aims to analyze the dynamics of the level of breeding work in the Alatau cattle population in the conditions of the Almaty region of the Republic of Kazakhstan.

\section{Materials and Research Methods}

The research work was carried out in 2019-2021. The research objects was the Alatau cattle, bred in different farms of the Almaty region, differing in their level and system of dairy cattle breeding.

The analysis of breeding work with the Alatau breed was carried out according to data from 5 farms: AIC Adal JSC of Enbekshikazakhsky district, Khilnichenko and K farm of Eskeldinsky district, Mamed farm of Karasay district, Plemzavod Almaty of Talgar district and Mezhdurechensk-Agro LLP of Ili district, Almaty region, Republic of Kazakhstan.

For a more detailed and substantiated analysis of the Alatau breed base, we analyzed the data from 2018 to 2020.

The materials for the research were the documents of the primary zootechnic and pedigree registration, as well as the downloading of the database from the Information and Analytical System (IAS) of dairy productivity (milk yield, the percentage of fat and protein in milk), the genealogical structure of herds.

Dairy productivity indicators (milk yield, percentage of fat and protein) have been entered into the IAS database since 2016 by independent laboratories. Monthly control milking is carried out by specially created mobile groups, which, in turn, take milk samples in parallel, with their further transportation to independent laboratories.

Thanks to modern information technology, breeding has become possible remotely. Improving the functions of the Information and Analytical System "Republican Animal Breeding System" in terms of control, analysis of accumulated data on the livestock population, analytical tools, as well as tools to automate the collection of data on milk quality, can significantly enhance the quality of recorded information and more fully use the existing database for carrying out selective and breeding work on farms. The collected data, improved by an additional control system, in combination with modern analytical tools will allow conducting economic and research work at a qualitatively new level (Alenayev et al., 2017; Alentayev et al., 2018). 
Linear assessment of first-calf cows by the main exterior traits was performed from the 30th to the 150th day of lactation, $2 \mathrm{~h}$ before the next milking.

The evaluation of first-calf cows was carried out by classificators, who had the appropriate certificate for the right to classify animals and registered in the IAS with their AWS-classifier (Alentayev et al., 2018).

Assessment of constitutional type is carried out on a 9-point scale, which, in turn, provides an opportunity to get an objective idea of individual animals and herds as a whole and allows livestock specialists to select breeders to correct and eliminate certain deficiencies in the offspring's body points (Baimukanov et al., 2021).

The results of linear assessment of the body type in first-calf cows in the studied farms were obtained through the AWS-classifier in the IAS.

The presented data of qualitative and quantitative indicators of dairy productivity were requested and received through the AWS of the Chamber (automated workstation) in the Republican Chamber of dairy cattle breeding of dairy and combined breeds.

To establish the genealogical structure of the herds, the characteristics of the servicing bulls of the Alatau and Swiss breeds, given in the pedigree certificates, were studied.

The analysis of the research results was done using common methods of statistical data processing used in biological research (Chindallyev et al., 2018; Baimukanov et al., 2019).

The research results were processed on a Personal Computer (PC) by statistical programs "MS Excel". The reliability of the difference in indicators (P) was determined by Fisher's criterion (Karamayev et al., 2019).

\section{Research Results}

Since 2011, in Kazakhstan, the Republican Chamber for Dairy and Combined Cattle Breeds (Chamber) has been operating, which includes: Holstein, Black-and-white, Alatau, Simmental, Aulieata, Red-Steppe and Swiss breeds, in which, directly, the pedigree cattle database is copied from the Information and Analytical System (IAS).

According to the results of the Republican Chamber, as of January 1, 2021, the number of registered pedigree cattle was 130347 animals. It was found that a significant livestock population is occupied by the Simmental breed (39.4\%), Holstein black-and-white - $30.0 \%$, black-and-white - $17.4 \%$, Alatau - $6.8 \%$ and the rest $-6.5 \%$ (Fig. 1).

As of 01.01.2021, the total number of Alatau cows in the studied farms was 1578 heads, of which the largest livestock population in the Khilnichenko and $\mathrm{K}$ farm is 612 animals or $41.1 \%$, the smallest in Mezhdurechensk-Agro LLP - 58 animals or $3.7 \%$ (Fig. 2).
During the tested period, in 2020, there was a decrease in livestock for all farms by $17.3 \%$ compared to 2018 , in 2019 this level decreased by $22.8 \%$ compared to 2018 . The decrease in the number of cows is due to the intensification of production and the herd renewal for more productive livestock.

The number of livestock makes it possible to analyze the quantitative and qualitative characteristics of the pedigree base of the Alatau cattle raised in the studied farms.

Qualitative and class composition. The main factor in advancing the productive and breeding qualities of livestock is the efficiency of the breeding work. It was found that the share of cows was $44.5 \%$, bred heifers and heifers of 18 months old and older $-25.8 \%$ and heifers under 18 months - $22.5 \%$, which is quite consistent with the structure of the herd for breeding and selective and breeding work (Table 1 and Fig. 3).

In terms of the qualitative composition, the experimental animals of the herd had rather high indicators, for example, the total livestock of animals was assigned to the elite-record class $-52.0 \%$, the elite class $-39.3 \%$. In terms of cows, $79.1 \%$ were assigned to the elite-record class, $20.6 \%$ to the elite, which fully meets the regulations of zootechnic norms for further breeding and improving the Alatau cattle breed (Alentayev et al., 2018).

The variability dynamics of milk production for 20162020 indicate an increase from 2016 compared to 2020 by $13.3 \%$, for agricultural producers - $40.7 \%$ (Fig. 4).

The variability dynamics of dairy productivity of breeding cows for 305 days of lactation (data of the Republican Chamber), for 5 years from 2016 to 2020, in a comparative aspect between full-age cows and first-calf cows, shows an increase in cows by $17.0 \%$, in first-calf heifers - 25.3\% (Fig. 5).

The dairy productivity of the studied Alatau cattle breed according to the last completed lactation showed the average milk yield per cow for 305 days in 2020 (5472 \pm 100.4$)$, in comparison with 2018 (4472 \pm 151.9$)$ increased by $22.4 \%$ (Table 2 ).

\section{The Fat and Protein Contents in Milk Varied Slightly}

Several factors impact on the milk yield of cows depending on lactation: The efficiency of cow milking by dairy women, the provision of the veterinary service and the genotype of the cows themselves.

It is known that the main criterion for selecting livestock for a group is the breed standard indicator and it is the main guideline when choosing cows. So the productivity of the first calving cows exceeds the breed standard by $250 \%$ in Alatau breed.

In the research, not only the amount of milk received from animals has been studied, but also its qualitative characteristics, which are the most important indicators of the economic activities of organizations in dairy farming. 
Analyzing the indicators of dairy production for three years 2018-2020 (Table 3), we note that the average milk yield of cows in the experimental herds over the past 3 years has tended to decrease, although in general for all farms the average level of milk yield has not changed $5491 \mathrm{~kg}$ (2018) $5153 \mathrm{~kg}$ (2019) and $5156 \mathrm{~kg}$ (2020). However, in the farm "Mamed", the level of development of milk yield over the past 2 years has significantly decreased on average by $856 \mathrm{~kg}$. Decrease in lactation activity in all analyzed farms. The reason for this may be the difficult climatic period, when farms experienced difficulties in procurement of succulent fodder.

The results of studies of the productivity of the Alatau cows indicate that the highest indices are observed in the farms Mamed and Mezhdurechensk-Agro LLP. It should be noted that less productive animals are kept in the Khilnichenko and $\mathrm{K}$ farm, which is associated with a relatively poor feed supply.
According to Baimukanov et al. (2019) «The average milk yield of the studied herds per 1 cow was $5300 \pm 30 \mathrm{~kg}$ of milk, with a mass fraction of fat of $3.74 \pm 0.02 \%$, the mass fraction of protein of $3.16 \pm 0.01 \%$, with a content of $324.7 \pm 23.8$ thous. of somatic cells. The most productive were the cows of the Holstein breed, their productivity over the Alatau breed was $694 \mathrm{~kg}(\mathrm{P}>0.99)$, over the black-and-motley breed it was1446 $\mathrm{kg}(\mathrm{P}>0.999)$, over the Simmental breed it was $1982 \mathrm{~kg}(\mathrm{P}>0.999)$, over the red steppe - $2038 \mathrm{~kg}(\mathrm{P}>0.999)$, no significant difference was found in the content of fat and protein of cow. Somatic cells were within normal limits. When studying the dynamics of milk yields according to lactation, it is established that the milk productivity of the Alatau breed is characterized by growth $(4844 \ldots$ $5679 \ldots 5458 \mathrm{~kg}$ ) by the second-third lactation and gradual decrease $(4716 \ldots 4017 \mathrm{~kg})$ by the fifth.

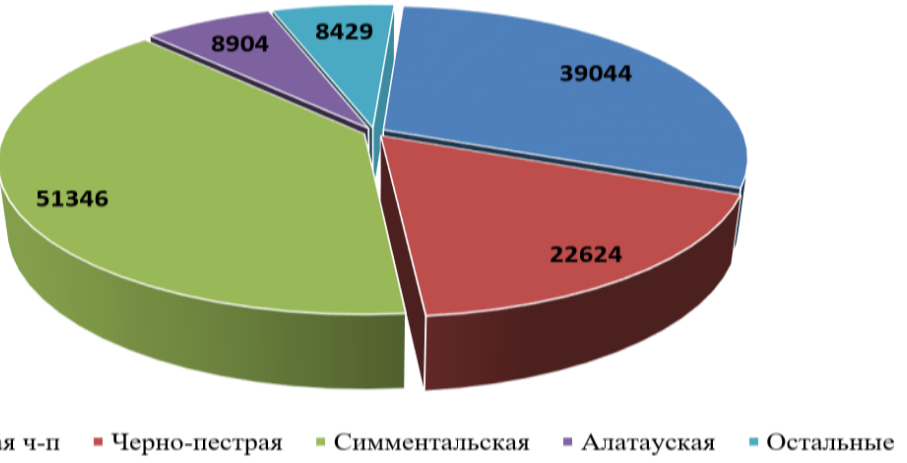

Note:

Голштинская ч-п (Holstein black-and-whi)

Черно-пестрая (Black-and-white)

Симментальская (Simmental)

Алатауская (Alatau)

Остальные (The others)

Fig. 1: The number of pedigree livestock registered in the Republican Chamber, in the context of breeds, animals

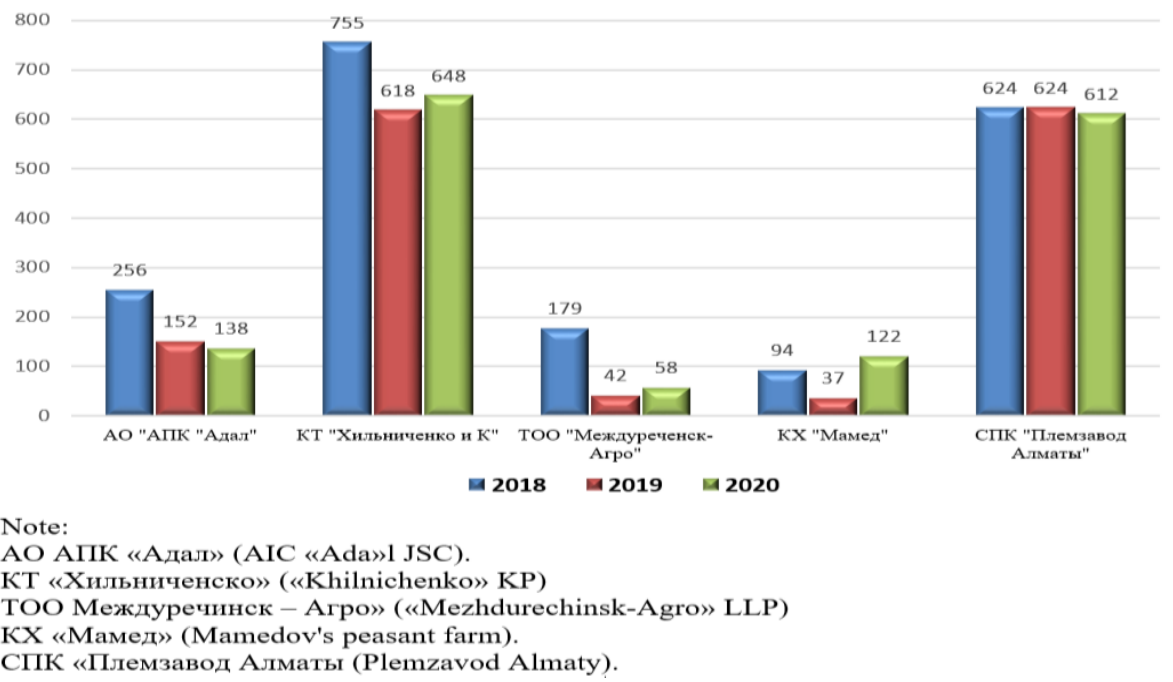

Fig. 2: Dynamics of the number of Alatau cows in the studied farms, animals 

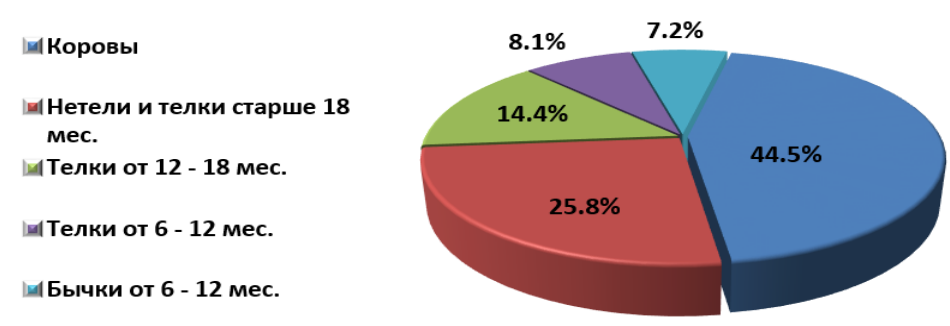

Note:

Коровы (Cows)

Нетели и телки старше 18 мес. (Heifers and heifers older than 18 months).

Телки от 12-18 мес. (Heifers from 12-18 months).

Телки от 6-12 мес. (Heifers from 6-12 months).

Бычки 6-12 мес. (Calves 6-12 months old)

Fig. 3: The herd structure of the studied farms

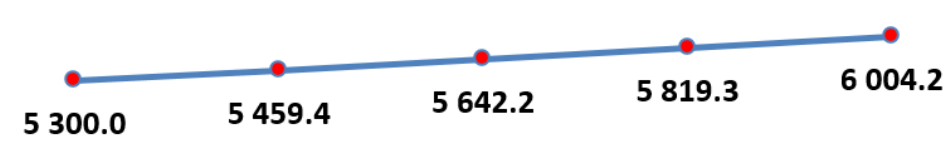

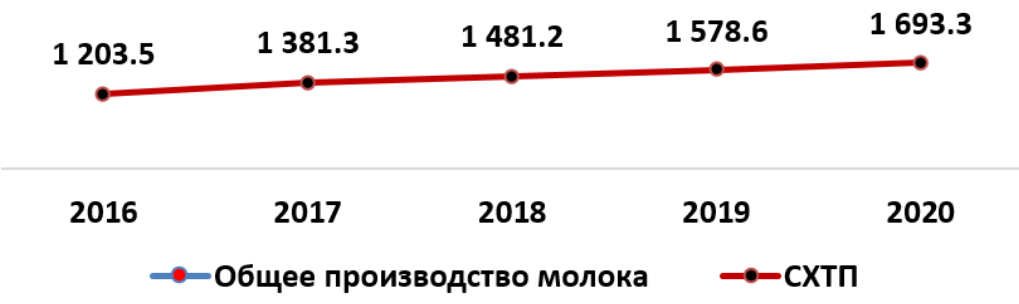

Note:

Общее производство молока (Total milk production)

Сельхозтоваропроизводители (Agricultural producers)

Fig. 4: Variability dynamics of milk production in the Republic of Kazakhstan in 2016-2020

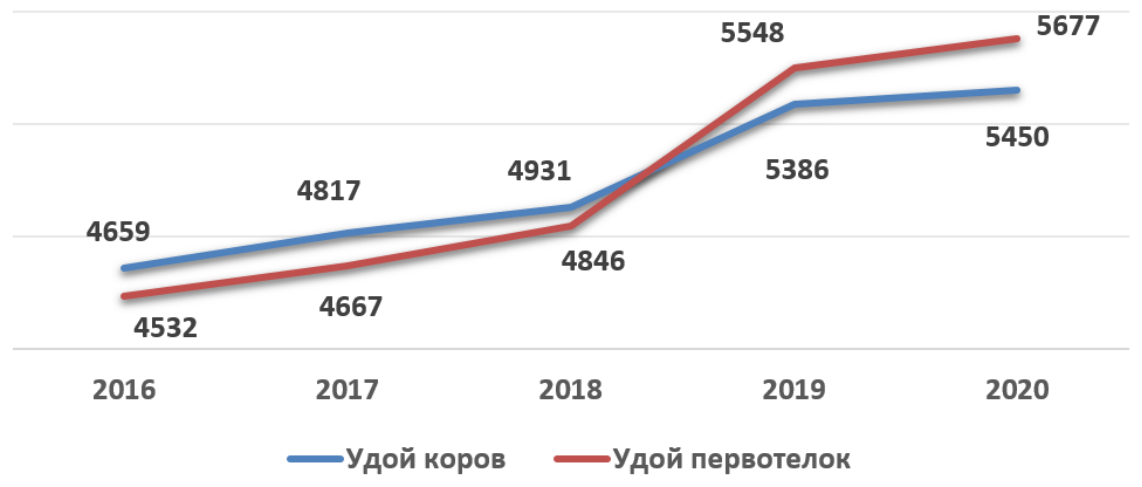

Note:

Удой коров (Milk yield of cows).

Удой первотелок (Milk yield of pervotelok)

Fig. 5: The variability dynamics of dairy productivity of Alatau cows of the herd 
Table 1: Class composition of the Alatau livestock of the experimental farms

\begin{tabular}{|c|c|c|c|c|c|c|c|}
\hline \multirow[b]{3}{*}{ Gender and age groups of animalsx } & \multirow[b]{3}{*}{$\mathrm{n}$} & \multicolumn{6}{|c|}{ Class composition } \\
\hline & & \multicolumn{2}{|c|}{ Elite Record } & \multicolumn{2}{|l|}{ Elite } & \multicolumn{2}{|l|}{ I class } \\
\hline & & animals & $\%$ & animals & $\%$ & animals & $\%$ \\
\hline Total Including: & 3548 & 1845 & 52.0 & 1394 & 39.3 & 309 & 8.7 \\
\hline Cows & 1578 & 1248 & 79.1 & 325 & 20.6 & 5 & 0.3 \\
\hline Bred heifers and heifers over 18 months old & 915 & 292 & 31.9 & 562 & 61.4 & 61 & 6.7 \\
\hline Heifers from $12-18$ months & 512 & 243 & 47.5 & 210 & 41.1 & 58 & 11.4 \\
\hline Heifers from 6 - 12 months & 289 & 133 & 46.1 & 108 & 37.2 & 48 & 16.7 \\
\hline bull-calves from 6 - 12 months & 254 & 59 & 23.2 & 105 & 41.5 & 90 & 35.3 \\
\hline
\end{tabular}

Table 2: Dairy productivity of the studied Alatau cows

\begin{tabular}{lllll}
\hline № & Year & Milk yield, kg & Fat, \% & Protein, \% \\
\hline 1 & 2018 & $4472 \pm 151.9$ & $4.15 \pm 0.12$ & $3.65 \pm 0.07$ \\
2 & 2019 & $4862 \pm 138.0$ & $4.05 \pm 0.04$ & $3.70 \pm 0.03$ \\
3 & 2020 & $5472 \pm 100.4$ & $4.10 \pm 0.16$ & $3.68 \pm 0.02$ \\
\hline
\end{tabular}

Table 3: Dairy productivity of first-calf cows of the Alatau breed for 2018-2020

\begin{tabular}{|c|c|c|c|c|c|}
\hline \multirow[b]{2}{*}{ Name of the farm (livestock) } & \multicolumn{5}{|l|}{ Traits } \\
\hline & Milk yield, kg & $\delta, \mathrm{kg}$ & $\mathrm{Cv}, \%$ & Fat content, $\%$ & Protein content, $\%$ \\
\hline \multicolumn{6}{|l|}{2018} \\
\hline "APK" Adal" JSC(n = 91) & $5167 \pm 275.4$ & 1811.6 & 34.0 & $3.69 \pm 021$ & $3.37 \pm 0.14$ \\
\hline Khilnichenkoand K ( $\mathrm{n}=103)$ & $4463 \pm 83.6$ & 613.8 & 14.4 & $3 . .90 \pm 0.07$ & $3.33 \pm 0.01$ \\
\hline Mamed $(n=36)$ & $6741 \pm 219.4$ & 1383.9 & 19.9 & $3.79 \pm 0.04$ & $3.25 \pm 0.01$ \\
\hline PlemzavodAlmaty $(\mathrm{n}=126)$ & $4655 \pm 126.5$ & 1110.4 & 40.0 & $3.67 \pm 0.15$ & $3.25 \pm 0.04$ \\
\hline Mezhdurechensk-Agro LLP $(n=68)$ & $6430 \pm 440.3$ & 1333.7 & 20.6 & $3.82 \pm 0.2$ & $3.23 \pm 0.04$ \\
\hline Total/Average $(\mathrm{n}=424)$ & $5491 \pm 2294$ & 927.8 & 168 & $3.77 \pm 0.13$ & $3.27 \pm 0.07$ \\
\hline \multicolumn{6}{|l|}{2019} \\
\hline "APK" Adal" JSC (n= 91) & $5327 . .8 \pm 2829$ & 1811.6 & 34.0 & $3.73 \pm 0.17$ & $3.37 \pm 0.14$ \\
\hline Khilnichenkoand $\mathrm{K}(\mathrm{n}=103)$ & $4258.5 \pm 843$ & 613.8 & 144 & $3.91 \pm 0.01$ & $3.33 \pm 0.01$ \\
\hline Mamed $(\mathrm{n}=36)$ & $6932.9 \pm 230.6$ & 1383.9 & 199 & $3.83 \pm 0.01$ & $3.25 \pm 0.01$ \\
\hline Plemzavod Almaty $(\mathrm{n}=126)$ & $47742 \pm 127.3$ & 1110.4 & 40.0 & $3.68 \pm 0.05$ & $3.25 \pm 0.04$ \\
\hline Mezhdurechensk-Agro LLP $(n=68)$ & $64734 \pm 4445$ & 1333.7 & 20.6 & $3.84 \pm 0.02$ & $3.23 \pm 0.04$ \\
\hline Total/Average $(n=424)$ & $51530 \pm 2543$ & 1250.7 & 25.8 & $377 \pm 0.08$ & $3.30 \pm 0.08$ \\
\hline \multicolumn{6}{|l|}{2020} \\
\hline "APK" Adal" JSC (n= 81) & $5127.8 \pm 272.8$ & 1750.6 & 33 & $4.00 \pm 018$ & $3.35 \pm 0.15$ \\
\hline Khilnichenkoand K $(\mathrm{n}=103)$ & $4458.5 \pm 85.3$ & 613.8 & 13.5 & $4.10 \pm 0.01$ & $3.50 \pm 0.02$ \\
\hline Mamed $(n=36)$ & $6076.9 \pm 234.7$ & 1415.9 & 19.9 & $3.83 \pm 0.01$ & $3.40 \pm 0.02$ \\
\hline Plemzavod Almaty $(\mathrm{n}=161)$ & $4774.2 \pm 115.5$ & 950.4 & 21.2 & $3.75 \pm 0.05$ & $3.44 \pm 0.05$ \\
\hline Mezhdurechensk-Agro LLP $(n=68)$ & $5440.4 \pm 450.5$ & 1347.7 & 20.2 & $3.95 \pm 0.02$ & $3.52 \pm 0.04$ \\
\hline Total/Average $(n=449)$ & $5176 \pm 245.7$ & 1215.7 & 21.5 & $3.92 \pm 0.07$ & $3.40 \pm 0.07$ \\
\hline Olsen et al. $(2020)$ & $6604 \pm 81.4$ & & & $3.81 \pm 0.07$ & \\
\hline
\end{tabular}

On average, for all lactations, cows of this breed brought $5123 \pm 275.4 \mathrm{~kg}$. The dairy productivity of Holstein cows is increased by the fifth lactation, without recessions. On average, for cows of black and motley breed for all lactations, the milk yield was $4671 \pm 190 \mathrm{~kg}$. Dynamics of milk yield of the Simmental breed increases from the first to the second lactation $(3917 \ldots 4035 \mathrm{~kg})$, in the third it decreases $(4035 \ldots 3334 \mathrm{~kg})$, from the fourth to the sixth lactation the sequence increases» (Asylbekovich et al., 2019).

The obtained data confirm the need for breeding and breeding work to improve the quality of milk
(Karamayev et al., 2019; Semenovich et al., 2019; Shamshidin et al., 2019).

Exterior and constitutional features of the Alatau cattle. When maintaining a pedigree base in selective and breeding work, the main attention is paid to the exterior and constitutional features of animals, which not only show the term of their economic use, but are also associated with the level of dairy productivity of livestock. In the context of farms, linear assessment of the constitutional type of first-calf heifers of the Alatau breed indicates a small variation in traits between the studied farms and those close to the optimal scores of 
the desired type of first-calf heifers of the Alatau breed (Table 4).

The first heifers of the farm "Mamed" were distinguished by their height (average 143-144 cm), the animals in the Khilnichenko and $\mathrm{K}$ farm were the shortest (average $138-140 \mathrm{~cm}$ ). Medium girth and body depth, wide chest, moderate pelvic inclination and the rear width. Body type refers to more milk forms. In terms of limbs, the animals were also characterized by moderate stance close to the desired type. As for the udder - close to the bath-shaped, with a high deep udder and correct positioning of the rear and front teats. It should be noted that the animals of the farm "Mamed" distinguished themselves by a more approximate assessment of the joining of the front udder lobes, a deep udder cleft and the height of joining of the rear udder part, which characterizes them with good morphological and functional properties.

The correlative interrelation of first-calf cows between milk yield for 305 days of lactation and body type, directly affecting the dairy productivity of animals, such as: Body type, joining of the front udder lobes, height and width of the udder rear part, central ligament (udder cleft) and udder height (Table 5).
The research results showed that the greatest interrelation was observed for the traits Central ligament $(\mathrm{r}=+0.36)$ and "Joining of the front udder lobes" $(r=+0.31)$, which indicates a moderate and positive relation, the least interrelation was in the trait "Udder rear part height" $(\mathrm{r}=+0.11)$. Thus, for all the observed traits, a weak, moderate and positive relationship was observed, which indicates the conduct of selection and the improvement of these traits in the offspring when selecting parental pairs.

With a linear estimation of the physique of first-calf heifers, it is established that in cows of domestic breeds, the parameters correspond to the optimal points of the species and the indicators of the extremities, but the parameters of the udder differ sharply. All the data on productive and exteriors were entered into the program of the Information and Analytical System (IAS), where the estimated breeding value of the studied cows was automatically calculated. The average Estimated Breeding Value (EBV) for all breeds was 81.4. Among all breeds, the highest EBV level was determined in Holstein cows (84.3) of imported selection (Baimukanov et al., 2019).

Table 4: Linear assessment of the exterior of cows of the formed groups

\begin{tabular}{|c|c|c|c|c|c|c|}
\hline & \multirow[b]{2}{*}{ Optimalscores } & \multicolumn{5}{|l|}{ Farms } \\
\hline & & $\begin{array}{l}\text { Plemzavod } \\
\text { Almaty }\end{array}$ & Mamed & $\begin{array}{l}\text { Mezhdurechensk } \\
\text {-Agro LLP }\end{array}$ & $\begin{array}{l}\text { Khilnichenkoand } \\
\text { K Indicators }\end{array}$ & $\begin{array}{l}\text { "APK" } \\
\text { Adal" JSC }\end{array}$ \\
\hline Height & 9 & 7.0 & 8.7 & 8.2 & 6.7 & 7.4 \\
\hline Bodydepth & 7 & 6.2 & 7.2 & 7.1 & 6.2 & 6.5 \\
\hline Bodystrength & 8 & 8.6 & 8.4 & 8.4 & 8.7 & 8.5 \\
\hline Bodytype & 7 & 6.7 & 8.2 & 7.5 & 6.5 & 7.6 \\
\hline Rearposition & 5 & 5.7 & 5.5 & 5.4 & 6.2 & 6.4 \\
\hline Rearwidth & 8 & 6.4 & 7.4 & 6.8 & 6.3 & 7.2 \\
\hline Hind limbs positioning, side view & 5 & 4,3 & 5.3 & 5.9 & 5.7 & 4.0 \\
\hline Hoofpositioning (angle) & 6 & 5.2 & 6.6 & 5.2 & 6.4 & 6.8 \\
\hline Hind limbs positioning, back view & 7 & 5.5 & 5.8 & 5.4 & 6.6 & 6.1 \\
\hline Hockjoint & 9 & 8.0 & 8.4 & 7.8 & 7.5 & 7.9 \\
\hline Joining of front udder lobes & 9 & 8.3 & 8.8 & 8.6 & 8.6 & 8.2 \\
\hline Udderrearpart height & 6 & 5.7 & 6.2 & 5.5 & 6.0 & 5.8 \\
\hline Rearudderpartwidth & 8 & 6.9 & 7.4 & 6.8 & 6.7 & 6.4 \\
\hline Centralligament & 9 & 7.1 & 8.7 & 7.7 & 7.1 & 7.8 \\
\hline Udderdepth & 6 & 6.7 & 5.2 & 5.5 & 6.2 & 6.2 \\
\hline $\begin{array}{l}\text { Position of the front nipples towards } \\
\text { the center }\end{array}$ & 6 & 4.7 & 5.4 & 6.0 & 5.0 & 5.3 \\
\hline Nipplelength & 5 & 5.8 & 6.1 & 5.5 & 5.5 & 5.6 \\
\hline $\begin{array}{l}\text { Position of the rear nipples towards } \\
\text { the center }\end{array}$ & 5 & 6.6 & 7.1 & 6.1 & 7.3 & 6.7 \\
\hline
\end{tabular}

Table 5: Correlation interrelation of first-calf cows between milk yield for 305 days of lactation and body type in the context of farms

\begin{tabular}{ll}
\hline Traits & The interrelation of milk yield for 305 days of lactation \\
\hline Constitutionaltype & +0.28 \\
Joining of front udder lobes & +0.31 \\
Udderrearpart height & +0.11 \\
Udderrearpart width & +0.22 \\
Centralligament & +0.36 \\
Udderdepth & +0.19 \\
\hline
\end{tabular}




\section{Acknowledgement}

Source of funding: By the priority specialized field of program-targeted funding upon scientific, science and technical programs of the Ministry of Agriculture of the Republic of Kazakhstan "Development of animal breeding based on intensive technologies" URN BR10764965 "Development of technologies for keeping, feeding, rearing and reproduction in dairy cattle breeding using the adapted resource-energysaving and digital technologies"

\section{Author's Contributions}

Aidar Dastanbekuly Baimukanov: Responsible executor for research, collection and analysis of materials. Master of Zootechniks, Researche of ESPC Bayserke-Agro LLP, 3 Otegen Batyr str., Talgar District, Almaty Region, 041615, Kazakhstan, E-mail: hostpuf@gmail.com, ORCID: https://orcid.org/0000-0001-9669-864X

Yusupzhan Artykovich Yuldashbayev: Scientific consultant, author of a scientific idea. Academician of the Russian Academy of Sciences, Doctor of Agricultural Sciences, Professor, Director of the Institute of Animal Science and Biology, Professor of the Department of Private Animal Science, Russian State University Moscow Agricultural Academy named after K.A. Timiryazev, 127550 Moscow, Russian Federation, st.Timiryazevskaya 49, E-mail: zoo@ rgau-msha.ru. ORCID: https://orcid.org/0000-0002-7150-1131

Vladimir Alexandrovich Demin: Scientific consultant, co-author of a scientific idea. Doctor of Agricultural Sciences, Professor, Head of the Horse Breeding Department of the Federal State Budgetary Educational Institution of Higher Education "Russian State Agrarian University Moscow Agricultural Academy named after K.A. Timiryazev ". 127550, Russia, Moscow, st.Timiryazevskaya, 49 E-mail: deminmsha@mail.ru. ORCID: https://orcid.org/0000-0003-3201-3618

Taram Amkhatovich Magomadov: Executor. Doctor of Agricultural Sciences, Professor, Russian State Agrarian University - Moscow Agricultural Academy named after K.A. Timiryazeva, Moscow; e-mail: zoo@rgau-msha.ru; ORCID: https://orcid.org/0000-0003-0826-1021

Khamit Ablgazinovich Aubakirov: Head of research. Candidate of Agricultural Sciences, Associate Professor of the Department of Biotechnology, M.H. Dulati Taraz State University, Taraz, Kazakhstan. e-mail: hamit_a57@mail.ru, ORCID: https://orcid.org/0000-0003-2670-4834

\section{Ethics}

All the principles of scientific ethics have been observed during the research work, there is no conflict of interest.

\section{References}

Abugaliev, S. K., Rodionov, G., Chindaliyev, A. (2017). Variability of breeding characteristics of new intrabreed types of cattle in Kazakhstan [Izmenchivost' selektsionnykh priznakovnov ykh vnutriporodnykh tipov krupnogo rogatogo skota Kazakhstana]. Chief zootechnician. Moscow. No. 4. p. 20-27. (in Russ.).

Alenayev, A. S., Smailov, S. D., Baimukanov, D. A., \& Abdrakhmanov, K. T. (2017). Productivity of factory type"adal"of black-festive cattle in jsc"agro-industrial company"'adal". Bulletin of the national academy of sciences of the Republic of Kazakhstan, (5), 68-77.

Alentayev, A. S., Baimukanov, D. A., Smailov, S. D., Semenov, V. G., Abdrakhmanov, K. T., Begaliyeva, D. A., \& Omarov, M. M. (2018). Efficiency of breeding of the alatau breed of brown cattle in the" Adal" agro-industrial company JSC. Bulletin of the national academy of sciences of the Republic of Kazakhstan, (5), 12-29. doi.org/10.32014/2018.2518-1467.2

Baimukanov, D.A., Abugaliyev, S.K., Seidaliyev, N.B., Semenov, V.G., Chindaliyev, A.E., Dalibayev E.K., Zhamalov B.S., \& Muka Sh.B. (2019). Productivity and estimated breeding value of the dairy cattle gene pool in the Republic of Kazakhstan. Bulletin of national academy of sciences of the Republic of Kazakhstan. Volume 1, Number 377. P,p. 39 - 53 doi.org/10.32014/2019.2518-1467.5.

Baimukanov, D. A., Semenov, V. G., Seidaliyev, N. B., Tyurin, V. G., Musayev, S. A. (2021). Directed Calf Raising in the Conditions of Adaptive Technology. Archives of Razi Institute. Razi Vaccine \& Serum Research. doi.org/10.22092/ARI.2021.355581.1700

Begaliyeva, D. A., Alentayev, A. S., Ombayev, A. M., \& Baimukanov, D. A. (2017). Improvement of the Technology for Young-Stock Breeding of Black-andWhite Diary Cattle in the Southeast of Kazakhstan. OnLine Journal of Biological Sciences (http://thescipub. com/abstract/10.3844/ofsp. 11376). doi.org/10.3844/ojbsci.2017

Calsamiglia, S., Espinosa, G., Vera, G., Ferret, A., \& Castillejos, L. (2020). A virtual dairy herd as a tool to teach dairy production and management. Journal of dairy science, 103(3), 2896-2905. doi.org/10.3168/jds.2019-16714

Chindallyev, A. E., Baimukanov, D. A., Karynbayev, A. K., \& Chindallyev, E. (2018). Results of the targeted selective and breeding work of the simmental redand-motley breed of dairy cattle. Bulletin of the national academy of sciences of the Republic of Kazakhstan, (6), 34-38. doi.org/10.32014/2018.2518-1467.24 
Clasen, J. B., Fikse, W. F., Kargo, M., Rydhmer, L., Strandberg, E., \& Østergaard, S. (2020). Economic consequences of dairy crossbreeding in conventional and organic herds in Sweden. Journal of dairy science, 103(1), 514-528. doi.org/10.3168/jds.2019-16958

Karamayev, S. V., Bakayeva, L. N., Balakirev, N. A., Demin, V. A., Karamayeva, A. S., Soboleva, N. V., ... \& Baimukanov, D. A. (2019). Quality of colostrum in dairy breed cows with different dairy productivity. Bulletin of the national academy of sciences of the Republic of Kazakhstan, (3), 72-84. doi.org/10.32014/2019.2518-1467.71

Olsen, H. B., Heringstad, B., \& Klemetsdal, G. (2020). Genetic analysis of semen characteristic traits in young Norwegian red bulls. Journal of dairy science, 103(1), 545-555.

doi.org/10.3168/jds.2019-17291
Shamshidin, A. S., Kharzhau, A., Baimukanov, D. A., Sermyagin, A. A. (2019). Molecular genetic profile of Kazakhstan populations of cattle breeds. Bulletin of national academy of sciences of the Republic of Kazakhstan. Volume 6, pp, 154-162. doi.org/10.32014/2019.2518-1467.157

Shamshidin, A.S., Bisembayev, A.T., Saginbayev, A.K., Abylgazinova, A.T., Kozhahmetova, A.N. (2021). Dairy productivity of first-calf cows and their average age at first calving in the context News of the national academy of sciences of the Republic of Kazakhstan series of biological and medical. Volume 3, Number 345 p.p. 74-79. doi.org/10.32014/2020.2519-1629.83 